DOI 10.18551/rjoas.2021-04.18

\title{
HEMATOLOGY AND MICRONUCLEI ANALYSIS OF TILAPIA (OREOCHROMIS NILOTICUS) FROM SELOREJO RESERVOIR, NGANTANG, MALANG, INDONESIA
}

\author{
Dina Karina Farkha* \\ Master's Study Program, Department of Aquaculture, Faculty of Fisheries and Marine \\ Science, University of Brawijaya, Indonesia
}

\begin{abstract}
Arfiati Diana
Department of Aquatic Resource Management, Faculty of Fisheries and Marine Science, University of Brawijaya, Indonesia
\end{abstract}

\author{
Iranawati Feni \\ Department of Marine Science, Faculty of Fisheries and Marine Science, \\ University of Brawijaya, Indonesia
}

*E-mail: karinafarkhadin@gmail.com

\begin{abstract}
The hematology of Nile tilapia had studied in Selorejo Reservoir as eutrophic reservoir. Hematology of tilapia can be used to detect physiological changes in fish due to environmental changes. This research was conducted from February to March 2019 by using a survey method to determine the hematological structure and micronuclei of tilapia from Selorejo Reservoir. Sampling was carried out 4 times in a week at three different stations. Researcher took 105 fish by using hand line and gill net. The measurement of water quality (temperature, $\mathrm{pH}$, dissolved oxygen and total organic matter) and data analysis, researcher employed the statistical $T$ test of Minitab application. The results of hematology analysis of tilapia indicated that the number of erythrocytes ranged from 1.489 .967 - 1.656 .658 cells/ mm3; leukocytes ranged from $91.305-104.648$ cells / mm3; hemoglobin ranged from $9-10 \mathrm{~g} \%$; hematocrit ranged from $24,3-28,2 \%$ and the amount micronuclei ranged from 8,2 to 9,6 cells/1000. It can be stated that the Hematology of tilapia is still within the normal range. Furthermore, the calculation of the hematology $T$ test of tilapia caught with fishing rods and gill net is not significantly different. In addition, the results of water quality parameter's measurements indicate fine condition for the growth of tilapia; the temperatures range from $27,8-28^{\circ} \mathrm{C}$; $\mathrm{pH}$ value is $7-8$, dissolved oxygen is $7,5-$ $8,38 \mathrm{mg} / \mathrm{L}$ and Total Organic Matter is $4,78-18,33 \mathrm{mg} / \mathrm{L}$. It can be inferred that the hematology and micronuclei of tilapia from Selorejo Reservoir are still within the normal range even though the water reservoir has eutrophic status. Thus, the community and the government are encouraged to monitor the condition of Selorejo Reservoir to maintain fish healthy.
\end{abstract}

\section{KEY WORDS}

Blood fish, Nile fish, dam, water quality, water resource, management.

Selorejo Reservoir is used as a spot for tourism and fishing activities. The fish commonly found in Selorejo Reservoir are local fish originated from the rivers that enter the reservoir such as red 'wader' fish (Barbodes binotatus), 'mujair' fish (Mozambique tilapia) and tilapia (Oreochromis niloticus) in addition to the seeds of tilapia which are also stocked in the reservoir according to the representative of Perum II Office of Malang Regency. The settlements around Selorejo Reservoir produce domestic waste which will eventually enter the reservoir. Moreover, the agricultural sector around the reservoir also uses NPK fertilizer so that its produced waste will also enter the reservoir [1].

The organic materials that enter the reservoir will accumulate and will cause the formation of toxic compounds for fish called as ammonia. If the ammonia level is high, the 
fish's ability to excrete ammonia will also be reduced. Later on, it will cause an increase of ammonia level within the tissues and blood of fish, which is in turn, will increase blood $\mathrm{pH}$. In the end, fish will be in stressful condition since the hemoglobin in the blood cannot bind oxygen [2].

Hematology is a health index for some fish species. It can also detect the physiological changes such as stress due to exposure to unwanted pollutants, diseases, metals in water and hypoxic conditions [3]. Next, the hematological variables include the percentage of blood volume consisting of red blood cells (erythrocytes), white blood cells (leukocytes), hematocrit or $\mathrm{Ht}$ and hemoglobin levels [4]. This study is aimed to determine the hematology structure and micronuclei of tilapia (Oreochromis niloticus) of Selorejo Reservoir, Ngantang District, Malang Regency.

\section{MATERIALS AND METHODS OF RESEARCH}

This research employed a survey method in which the samples were randomly taken. There were three different stations for sampling and measurement of water quality. Station 1 was within the reservoir inlet. Station 2 was in the middle of the reservoir and station 3 was at the outlet of the reservoir.

Fish samples were obtained from fishermen who used hand line and gill net fishing gear with a total number of 105 fish. The samples of tilapia blood (Oreochromis niloticus) were examined to observe the hematological conditions including erythrocytes, leukocytes, micronuclei, $\mathrm{Hb}$ and hematocrit measurements which were supported by water quality parameters (physical and chemical), such as temperature, $\mathrm{pH}$, dissolved oxygen and total organic matter. The calculation of the number of erythrocytes, micronuclei and leukocytes was performed by using hand tally counter under a microscope. Meanwhile the hemoglobin measurement was carried out by using a haemometer. Then, the hematocrit measurement was carried out by using a centrifuge hematocrit.

Statistical analysis using the SPSS IBM 22 application with a statistical T test with a $95 \%$ confidence level was used to determine whether there were hematological differences between fish caught with gill nets and hand lines.

\section{RESULTS AND DISCUSSION}

The highest average number of red blood cells $\left(\right.$ cells $/ \mathrm{mm}^{3}$ ) was obtained from fish at station 3 which was 1.656 .658 cells $/ \mathrm{mm}^{3}$, and the lowest number of erythrocytes was taken from fish at station 2 which was $1.489 .967 \mathrm{cells} / \mathrm{mm}^{3}$ and the number of erythrocytes in fish from the station 1 was 1.514 .350 cells $/ \mathrm{mm}^{3}$ (Figure 1). The high number of erythrocytes from the three stations was still in the normal range. The number of normal erythrocytes in tilapia ranged from 20.000 to 3.000 .000 cells $/ \mathrm{mm}^{3}$ [5]. In addition to the condition of the aquatic environment, the factors that cause the high and low number of erythrocytes are size, sex, physical activity and age of fish. The ages of Erythrocytes and leukocytes are \pm 4 6 months old [6]. The high number of erythrocytes at station 3 is due to the fish sizes are larger than fish at station 1 and 2.

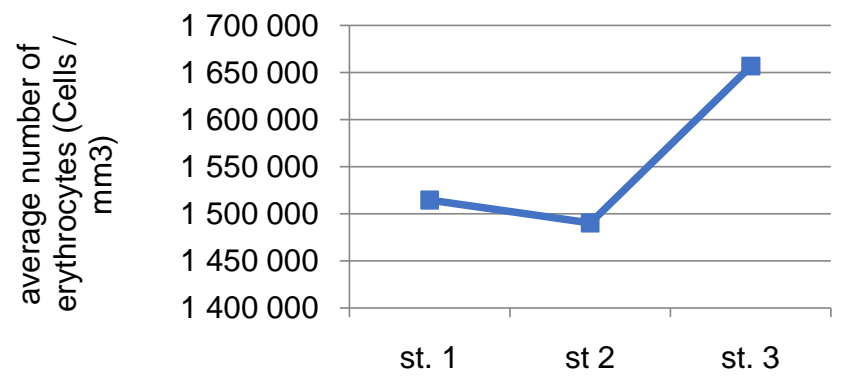

Figure 1 - Average number of erythrocytes (Cells $/ \mathrm{mm}^{3}$ ) (Source: Field Data) 
The highest average number of white blood cells (cells $\mathrm{mm}^{3}$ ) in fish from station 2 was equal to 104.648 .3 cells $/ \mathrm{mm}^{3}$. Meanwhile the lowest number of leukocytes was found in fish from station 3 indicating 91.305 cells $/ \mathrm{mm}^{3}$ and the number of leukocytes in fish from station 1 was 102.358 cells $/ \mathrm{mm}^{3}$ (Figure 2). The high and low number of leukocytes from the three stations was still within the normal range. Normal leukocyte counted in tilapia ranges from $20.000-150.000$ cells $/ \mathrm{mm}^{3}$ [7]. Factors affecting the high and low number of leukocytes are environmental conditions, age and condition of fish [8]. The number of leukocytes at stations 1 and 2 are higher because of the condition of the aquatic environment which contains high level of organic matter. In addition, at station 3 the leukocyte count is low because the condition of water quality is in accordance with fish growth. Leukocytes will increase if the fish is in stressful conditions for example heat stress and when the fish suffers from a disease [9]. While the low number of leukocytes indicates that the fish is healthy.

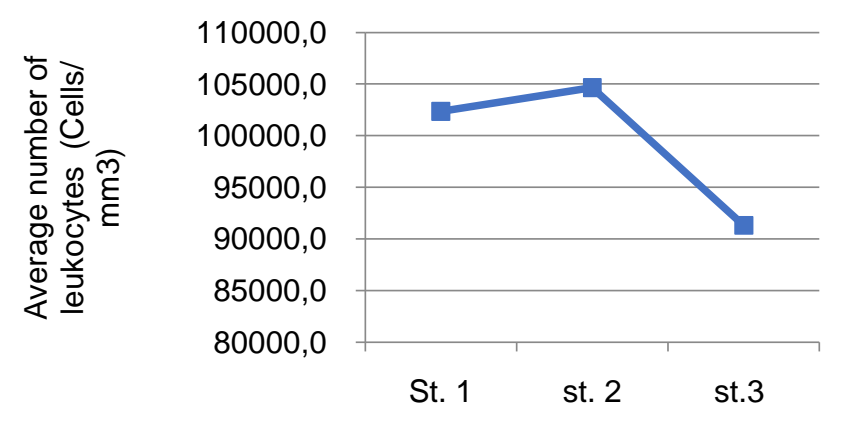

Figure 2 - Average number of leukocytes (Cells/ $\mathrm{mm}^{3}$ ) (Source: Field Data)

There were three different levels of tilapia's $\mathrm{Hb}$. The highest average hemoglobin level of tilapia taken from station 3 was equal to $10 \mathrm{~g} \%$, the lowest hemoglobin level of tilapia taken from station 2 was $9 \mathrm{~g} \%$ and the amount of hemoglobin level of tilapia taken from station 1 was 9,2 g\% (Figure 3). The high and low hemoglobin levels of the tilapia of the three stations were still within normal range. Normal hemoglobin level in tilapia ranges between $9-11,1 \mathrm{~g} \%$ [10]. $\mathrm{Hb}$ is very closely related to the number of erythrocytes in fish blood and is affacted by several factors such as the presence of oxygen in the water and the number of erythrocytes [11]. If the number of erythrocytes increases, the oxygen-binding activity by hemoglobin will also increase due to the amount of oxygen in the blood, meanwhile the decreasing number of hemoglobin level in the blood is related to the low erythrocyte number [12].

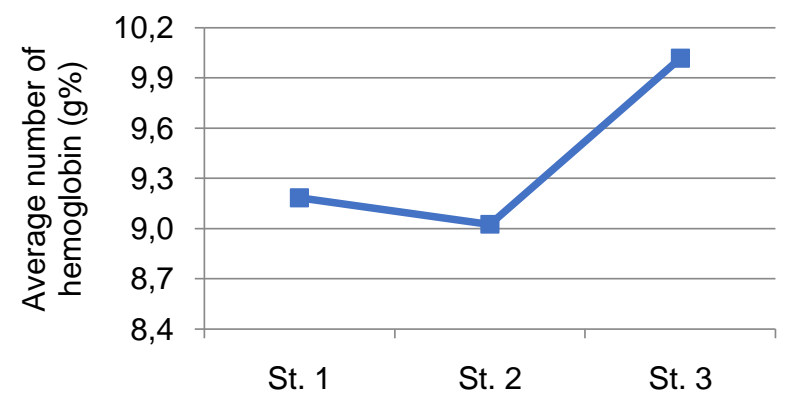

Figure 3 - Average number of hemoglobin (g\%) (Source: Field Data)

The highest average hematocrit number was taken from in fish at station 3 with $28,2 \%$, meanwhile the lowest hematocrit number was taken from station 2 with $24,3 \%$. Furthermore, the hematocrit number from station 1 was $27,9 \%$ (Figure 4). The high and low hematocrit numbers at the three stations are still in the normal range. Normal hematocrit number in tilapia ranges from $22-35,8 \%$ [13]. When the hematocrit value of tilapia is less than $22 \%$, it 
shows an indication of anemia. The variation in hematocrit number is high because it is greatly affected by water temperature and the number of erythrocytes. Hematocrit is directly proportional to the number of erythrocytes, and the hemoglobin in oxygen binding. Furthermore, it has an inverse comparison to leukocytes in the immune system [14].

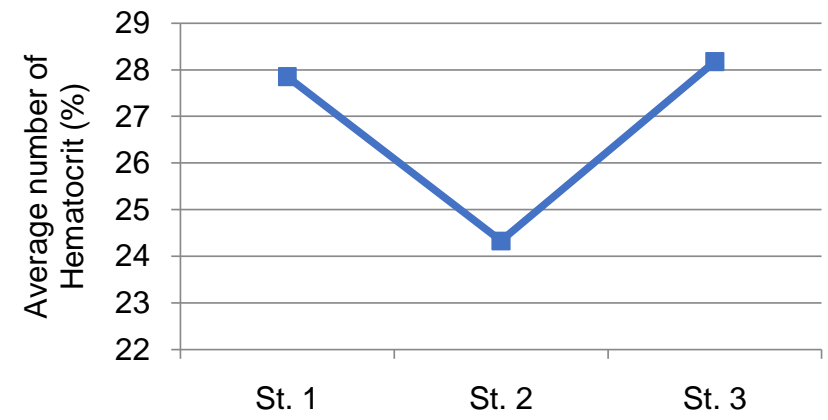

Figure 4 - Average number of Hematocrit (\%) (Source: Field Data)

The highest average number of micronuclei in fish was from station 2 with 9,6 cells/1000, while the lowest micronuclei number was from station 3 with 8,2 cells/1000. Next, the number of fish micronuclei from station 1 was 9,2 cells/1000 (Figure 5). The low number of micronuclei indicates that the fish is healthy. In addition, the increasing number of micronuclei by $25-30$ cells $/ 1000$ is due to the organism's exposure to waste and the presence of toxic substances in the body of the organism which cause a reaction between toxic substances with certain molecular structures of the organism [15].

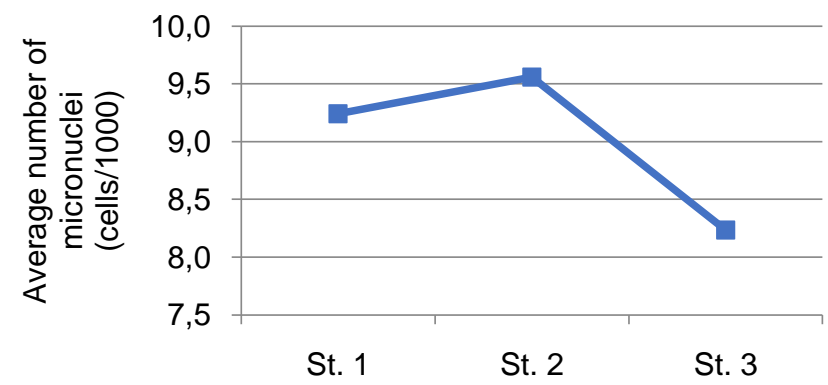

Figure 5 - Average number of micronuclei (cells/1000) (Source: Field Data)

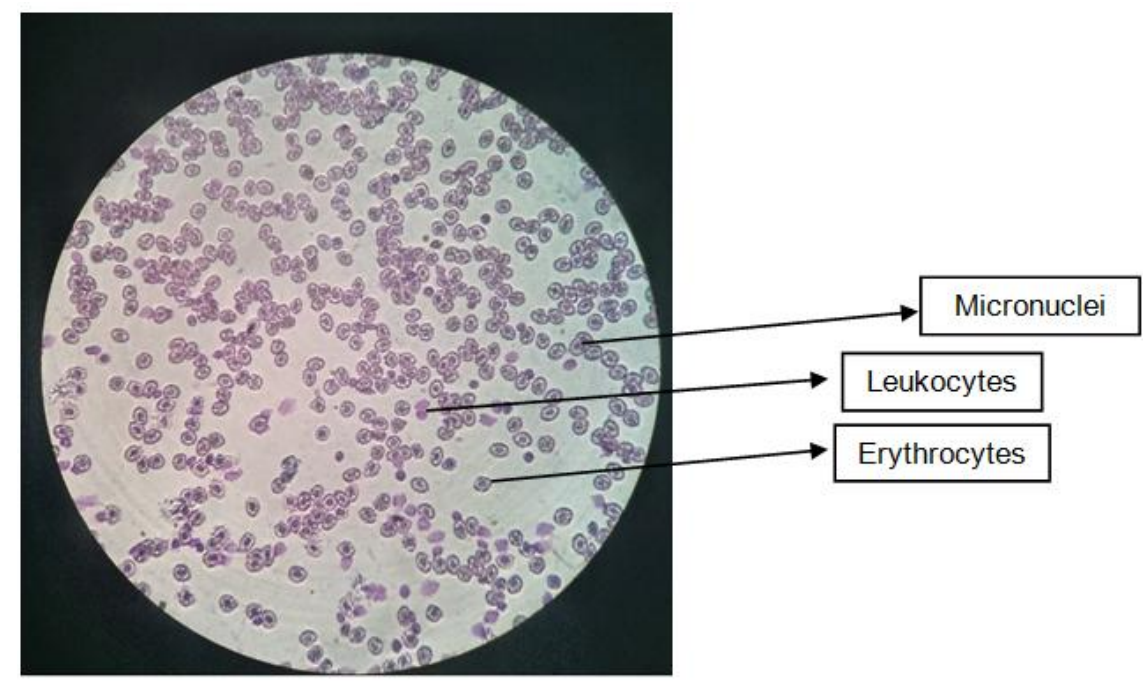

Figure 6 - Components of Oreochromis niloticus blood cells (Source: Research documentation) 
The statistical $T$ test was used to distinguish between the hematology of fish which were caught by using net fishing gear and hand line, with the statistical $\mathrm{T}$ test value between fishing gear and fishing rods with erythrocytes, namely $T$ value $(-0.76)<T$ table $(1.66543)$, leukocytes namely $T$ value (1.18) $<T$ table (1.66543), hemoglobin namely $T$ value $(-0.69)<T$ table (1.66543), hematocrit namely $T$ value $(-0.80)<T$ table (1.66543) and micronuclei namely $T$ value $(0.67)<T$ table $(1,66543)$. Furthermore, the obtained results were $T$ value $<$ $T$ table and $p$ value $>0.05$. It indicated that there was no difference or no influence of fish caught by using gill net and hand line. In terms of the number of erythrocytes, leukocytes, micronuclei, hematocrit value and hemoglobin level of tilapia, both fishing methods' results were similar.

The temperature obtained in this study ranged from $27,8-28,4^{\circ} \mathrm{C}$. The temperature was still in optimum condition for the growth of tilapia (Oreochromis niloticus). The optimum temperature for tilapia growth and development is between $25-30^{\circ} \mathrm{C}$ [16]. The decreased environmental temperature will cause erythrocyte degradation so that the process of respiration (breathing or taking oxygen) will be disrupted [17].

The $\mathrm{pH}$ value affected the metabolism of tilapia. The results of the study showed that $\mathrm{pH}$ values ranged from 7-8. The proper $\mathrm{pH}$ range for tilapia growth is $6,5-8,5$ [18]. $\mathrm{A}$ reservoir with low $\mathrm{pH}$ value will cause high ammonia concentration because the nitrification process runs slowly. High ammonia will cause a decrease in the number of blood cells, and oxygen levels in the blood [19].

The obtained dissolved oxygen level during the study ranged from 7,5 to $8,35 \mathrm{mg} / \mathrm{L}$. The optimal dissolved oxygen level for tilapia growth is more than $5 \mathrm{mg} / \mathrm{L}$ [20]. Oxygen level (dissolved oxygen) $<5 \mathrm{mg} / \mathrm{L}$ stimulates the formation of red blood cells which causes an increase in hemoglobin levels, the number of erythrocytes and hematocrit values [21].

The result of measurement of total organic matter level ranged from $8,33-18,33 \mathrm{mg} / \mathrm{L}$. The total organic matter content was $>12,5 \mathrm{mg} / \mathrm{L}$. It indicates that the water is eutrophic. The high nutrient content is due to the input of organic matter which underwent a decomposition process. Nitrogen left in the waters from household waste is in the form of nitrite $\left(\mathrm{N}-\mathrm{NO}_{2}\right)$ and nitrate $\left(\mathrm{N}-\mathrm{NO}_{3}\right)$. High nitrite level will harm fish because it can reduce the ability of blood to bind oxygen in the blood [22].

\section{CONCLUSION}

The hematology of Tilapia (Oreochromis niloticus) from Selorejo Reservoir is still in the normal range. Tilapia which is caught by using either fishing nets or hand line shows no difference in blood composition.

\section{ACKNOWLEDGEMENTS}

This research can be carried out well thanks to the help of various parties, for that researchers would like to thank the Head of Jasa Tirta 1 and the accompanying staff at Selorejo Reservoir with their cooperation, so that the research can be carried out properly.

\section{REFERENCES}

1. Pratiwi, E.O and R. W. Sayekti, "Studi penentuan status trofik dan daya tampung beban pencemaran air Waduk Selorejo," J. Mhs. Jur. Tek. Pengair., vol. 1, no. 9, pp. 1-7, 2018.

2. Modesto, K.A and C. B. R. Martinez, "Effects of Roundup Transorb on fish: Hematology, antioxidant defenses and acetylcholinesterase activity," Chemosphere, vol. 81, no. 6, pp. 781-787, 2010, doi: 10.1016/j.chemosphere.2010.07.005.

3. Faggio, C., F. Arfuso, G. Piccione, A. Zumbo, and F. Fazio, "Effect of three different anticoagulants and storage time on haematological parameters of Mugil cephalus (Linneaus, 1758)," Turkish J. Fish. Aquat. Sci., vol. 14, pp. 615-621, 2014, doi: 10.4194/1303-2712-v14_3_03.

4. Kulkarni, R.S, "Hematology of the Freshwater Fish, Notopterus notopterus in Relation to 
Physico-Chemical Characteristics of the Water," Int. Lett. Nat. Sci., vol. 40, pp. 19-23, 2015, doi: 10.18052/www.scipress.com/ilns.40.19.

5. UEDA, I.K, M. I. EGAMI, W. da S. SASSO, and E. R. MATUSHIMA, "Cytochemical aspects of the peripheral blood cells of Oreochromis (Tilapia) niloticus. (Linnaeus, 1758) (Cichlidae, Teleostei): part II," Brazilian J. Vet. Res. Anim. Sci., vol. 38, no. 6, pp. 273277, 2001, doi: 10.1590/s1413-95962001000600005.

6. Li, H.T, et al., "Oxidative stress parameters and anti-apoptotic response to hydroxyl radicals in fish erythrocytes: Protective effects of glutamine, alanine, citrulline and proline," Aquat. Toxicol., vol. 126, pp. 169-179, 2013, doi: 10.1016/j.aquatox.2012.11.005.

7. Holladay, S.D, B. J. Smith, and R. M. Gogal, "Exposure to formaldehyde at therapeutic levels decreases peripheral blood lymphocytes and hematopoietic progenitors in the pronephros of tilapia Oreochromis niloticus," Aquat. Biol., vol. 10, no. 3, pp. 241-247, 2010, doi: 10.3354/ab00282.

8. Osman, A.G.M, K. Y. AbouelFadl, A. E. B. M. Abd El Reheem, U. M. Mahmoud, W. Kloas, and M. A. Moustafa, "Blood Biomarkers in Nile tilapia Oreochromis niloticus niloticus and African Catfish Clarias gariepinus to Evaluate Water Quality of the River Nile," J. Fish., vol. 12, no. 1, pp. 1-15, 2018, doi: 10.21767/1307-234x.1000141.

9. Mogodan, A, I. Simionov, and Ștefan Petrea, "synergistic effect of thymus vulgaris and vitamin e on hematological profile, some blood biochemical indices and leukocyte reaction of oreochromis niloticus species," Sci. Pap. Ser. D. Anim. Sci., vol. 58, no. 2, pp. 217-228, 2020.

10. Wedemeyer G.A, and W. T. Yasutake, "Clinical methods for the assessment on the effect of enviromental stress on fish health." technical paper of the us departement of the interior fish and the wildlife service, 1977.

11. Yildiz, H.Y, G. Köksal, G. Borazan, and Ç. K. Benli, "Nitrite-induced methemoglobinemia in Nile tilapia, Oreochromis niloticus," J. Appl. Ichthyol., vol. 22, no. 5, pp. 427-426, 2006, doi: 10.1111/j.1439-0426.2006.00761.x.

12. Alkaladi, A, N. A. M. N. El-Deen, M. Afifi, and O. A. A. Zinadah, "Hematological and biochemical investigations on the effect of vitamin $E$ and $C$ on Oreochromis niloticus exposed to zinc oxide nanoparticles," Saudi J. Biol. Sci., vol. 22, no. 5, pp. 556-563, 2015, doi: 10.1016/j.sjbs.2015.02.012.

13. Panase, P, S. Saenphet, and K. Saenphet, "Biochemical and physiological responses of Nile tilapia Oreochromis niloticus Lin subjected to cold shock of water temperature," Aquac. Reports, vol. 11, no. April, pp. 17-23, 2018, doi: 10.1016/j.aqrep.2018.05.005.

14. Adhim, M.H, A. Zainuddin, T. W. C. Putranto, B. Irawan, and A. Soegianto, "Effect of sublethal lead exposure at different salinities on osmoregulation and hematological changes in tilapia, Oreochromis niloticus," Arch. Polish Fish., vol. 25, no. 3, pp. 173-185, 2017, doi: 10.1515/aopf-2017-0017.

15. Ozkan, F, S. G. Gündüz, M. Berköz, and A. Özlüer Hunt, "Induction of micronuclei and other nuclear abnormalities in peripheral erythrocytes of Nile tilapia, Oreochromis niloticus, following exposure to sublethal cadmium doses," Turkish J. Zool., vol. 35, no. 4, pp. 585-592, 2011, doi: 10.3906/zoo-0907-77.

16. Ismail, N.I.A, M. N. A. Amal, S. Shohaimi, M. Z. Saad, and S. Z. Abdullah, "Associations of water quality and bacteria presence in cage cultured red hybrid tilapia, Oreochromis niloticus × O. mossambicus," Aquac. Reports, vol. 4, pp. 57-65, 2016, doi: 10.1016/j.aqrep.2016.06.004.

17. Bhateria, R, and D. Jain, "Water quality assessment of lake water: a review," Sustain. Water Resour. Manag., vol. 2, no. 2, pp. 161-173, 2016, doi: 10.1007/s40899-015-00147.

18. Amal, M,N,A, M. Z. Saad, A. S. Zahrah, and A. R. Zulkafli, "Water quality influences the presence of Streptococcus agalactiae in cage cultured red hybrid tilapia, Oreochromis niloticus $\times$ Oreochromis mossambicus," Aquac. Res., vol. 46, no. 2, pp. 313-323, 2015, doi: 10.1111/are.12180.

19. Wang, J,et al., "Investigation of bathymetry and water quality of Lake Nam Co, the largest 
lake on the central Tibetan Plateau, China," Limnology, vol. 10, no. 2, pp. 149-158, 2009, doi: 10.1007/s10201-009-0266-8.

20. Shoko, A.P, S. M. Limbu, H. D. J. Mrosso, and Y. D. Mgaya, "A comparison of diurnal dynamics of water quality parameters in Nile tilapia (Oreochromis niloticus, Linnaeus, 1758) monoculture and polyculture with African sharp tooth catfish (Clarias gariepinus, Burchell, 1822) in earthen ponds," Int. Aquat. Res., vol. 6, no. 1, 2014, doi: 10.1007/s40071-014-0056-8.

21. Gaber, H.S, M. A. El-Kasheif, S. A. Ibrahim, and M. M. N. Authman, "Effect of water pollution in El-Rahawy drainage canal on hematology and organs of freshwater fish Clarias gariepinus," World Appl. Sci. J., vol. 21, no. 3, pp. 329-341, 2013, doi: 10.5829/idosi.wasj.2013.21.3.71192.

22. Krishna P.K, M. Ramesh, M. Saravanan, and N. Ponpandian, "Ecological risk assessment of silicon dioxide nanoparticles in a freshwater fish Labeo rohita: Hematology, ionoregulation and gill $\mathrm{Na}+\mathrm{K}+$ ATPase activity," Ecotoxicol. Environ. Saf., vol. 120, pp. 295-302, 2015, doi: 10.1016/j.ecoenv.2015.05.032. 